\title{
Deus ex-machina: uma análise do fenômeno da telerreligião na mídia brasileira
}

\author{
Deus ex-machina: an analysis of the electronic church phenomenon in the \\ Brazilian media
}

\author{
Deus ex-machina: un análisis del fenómeno de la iglesia electrónica en los \\ medios de comunicación de Brasil
}

Gilson Soares Raslan Filho ${ }^{l}$

\begin{abstract}
Resumo
Embora seja natural que o Brasil, país de colonização católica, teça sua cultura a partir dessa matriz, tal naturalização, quando nos defrontamos com a presença da religião na mídia - especialmente a Televisão, que tem especial atenção deste texto - ganha contornos que desnudam uma disputa mais profunda. Na guerra para manter sua hegemonia, a Igreja Católica, em sua diversidade, sempre esteve presente na programação da mídia eletrônica brasileira, seja com o acesso a concessões públicas, seja pela cessão de espaços pelos veículos seculares. Nos últimos anos, esse fenômeno foi recrudescido: o incremento da chamada telerreligião, controlada sobretudo por líderes neo-pentecostais, fez os líderes católicos se movimentarem em direção a uma maior presença no espectro midiático e muito especialmente do controle de canais de TV. Este artigo procura acompanhar táticas religiosas em busca de presença e controle dos meios eletrônicos de comunicação e, ao fim e ao cabo, se questiona: o que significa, para a tessitura do imaginário contemporâneo brasileiro, essa associação entre mídia e religião?
\end{abstract}

Palavras-chave: Mídia. Mercado religioso. Catolicismo. Neopentecostalismo. Brasil.

\begin{abstract}
Although it is natural that Brazil, a country of Catholic colonization, has tissue culture according to this matrix, this naturalization, in the presence of religion in the media, wins contours that expose a dispute deeper. In the war to maintain its hegemony, the Catholic Church, in its diversity, was always present in the programming of the electronic media in Brazil, either with access to public subsidies, whether for the allocation of spaces for secular vehicles. In recent years, this phenomenon was recrudescido: the increase in electronic church, mainly controlled by neo-Pentecostal leaders, did Catholic leaders to move towards a greater presence in the media spectrum. This article aims to follow religious tactics for the presence and control of the electronic media and and finally poses the question: what does it mean, for the fabric of contemporary Brazilian imagination, this association between the media and religion?
\end{abstract}

Keywords: Media. Religious market. Catholicism. Neo-Pentecostalism. Brazil.

\begin{tabular}{|c|c|}
\hline \multicolumn{2}{|r|}{ Acesse este artigo online } \\
\hline QR CODE: & $\begin{array}{l}\text { Website: } \\
\text { http://www.revistas.ufg.br/index.php/ci }\end{array}$ \\
\hline 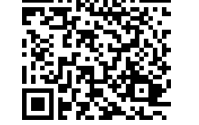 & $\begin{array}{l}\text { DOI: } \\
\text { http://dx.doi.org/10.5216/36979 }\end{array}$ \\
\hline
\end{tabular}

\section{Resumen}

A pesar de que es natural que Brasil, un país de la colonización católica, tiene el cultivo de tejidos de acuerdo con esta matriz, esta naturalización, ante la presencia de la religión en los medios de comunicación,

\footnotetext{
${ }^{1}$ Doutor em Comunicação e Cultura pela Universidade de São Paulo (USP), mestre em Estudos Literários e graduado em Comunicação Social pela Universidade Federal de Minas Gerais (UFMG). Professor na Universidade do Estado de Minas Gerais (UFMG). Brasil, Divinópolis, MG. E-mail: gilraslan@gmail.com
}

Comun. \& Inf., Goiânia, GO, v. 18, n. 2, p. 53-72, jul./dez. 2015 
gana contornos que ponen al descubierto una disputa más profunda. En la guerra para mantener su hegemonía, la Iglesia Católica, en su diversidad, siempre estuvo presente en la programación de los medios electrónicos de Brasil, ya sea con acceso a subvenciones públicas, ya sea por la asignación de los espacios por los vehículos seculares. En los últimos años, este fenómeno fue recrudescido: el aumento el aumento de la llamada iglesia electrónica, controlada principalmente por líderes neopentecostales, hizo líderes católicos para avanzar hacia una mayor presencia en el espectro de medios de comunicación. Este artículo pretende seguir tácticas religiosas en busca de la presencia y el control de los medios de comunicación electrónicos y, finalmente, planteala pregunta: ¿qué significa, para el tejido de la imaginación brasileña contemporánea, esta asociación entre los medios y la religión?

Palabras clave: Medios de Comunicación. Mercado religioso. Catolicismo. Neopentecostalismo. Brasil.

\section{INTRODUÇÃO}

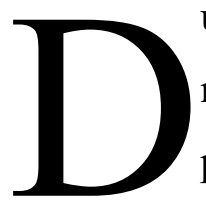

uas instituições sociais de transmissão simbólica; duas tecnologias de moralidade; duas máquinas que criam humanos e coletividades. Assim podem ser relacionados os mundos da comunicação social - ou antes: do sistema midiático secular - e da religião. Se, no caso das Igrejas nãocatólicas, muito especialmente as neo-pentecostais surgidas em território estadunidense, a relação entre mídia e religião parece ser, mais do que simbiótica, necessária, no caso do catolicismo essa relação, se se pode resumí-la em uma palavra, é de ambiguidade.

É dessa ambiguidade que trata este texto: nele, é feita uma análise do fenômeno da telerreligião, das igrejas eletrônicas, no Brasil, sobretudo em relação à $\mathrm{TV}$, dispositivo que ainda concentra grande poder na construção do imaginário brasileiro. ${ }^{2}$ Mais ainda, na esteira da análise empreendida, é realizada, senão uma reflexão, uma provocação, desde já anunciada: que significa, para as sociabilidades e as subjetividades brasileiras, a crescente presença de programação e canais ligados a grupos religiosos na mídia, em geral, e muito especialmente na TV brasileira? Haveria nessa relação algum tipo de simbiose? Com que propósito? Com que consequências?

Trata-se, todavia, de provocações apenas. Este texto, a rigor, acompanha a evolução do fenômeno da telerreligião no Brasil. A tarefa aqui empreendida se esforça, num primeiro momento, por localizar a evolução e contínuo progresso do controle de meios eletrônicos por agremiações religiosas. Nessa busca, que tem como finalidade compreender a crescente presença da religião na $\mathrm{TV}$, foi forçoso realizar um retorno ao início dessa relação, com o rádio. $\mathrm{O}$ que se observou nessa retrospectiva e a despeito de uma possível reação tardia da

\footnotetext{
${ }^{2}$ Uma pesquisa da Secretaria de Comunicação Social da Presidência da República (BRASIL, 2014) indica que os brasileiros ainda têm na televisão seu canal de informação e entretenimento preferencial. Segundo a pesquisa, $95 \%$ dos brasileiros assistem à TV e 73\% assistem-na diariamente. Em média, os brasileiros consomem quatro horas diárias de programação televisiva. Os dados ainda mostram um aumento desse consumo em $2014 \mathrm{em}$ relação a 2013.
}

Comun. \& Inf., Goiânia, GO, v. 18, n. 2, p. 53-72, jul./dez. 2015 


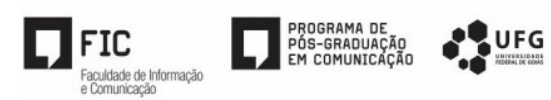

Igreja Católica - que respondeu de forma sistemática ao crescimento do controle de meios de comunicação por suas concorrentes, as neo-pentecostais sobretudo, apenas quando se observava o evidente crescimento da telerreligião não-católica em terras brasileiras - não pode ser considerado como inércia do catolicismo. Ao contrário: pode-se observar que, se o controle de canais de TV foi de fato uma reação à presença cada vez maior de agremiações não-católicas, a relação entre a Igreja Católica e a mídia é bastante antiga, o que acaba por reforçar uma aproximação importante entre líderes religiosos católicos e sociedade política, o que, obviamente, permitiu que houvesse facilidades para conseguir concessões de meios eletrônicos de comunicação - o que, no caso do não-catolicismo, só se averiguou nos últimos 20 anos, com o incremento da chamada bancada evangélica no Congresso Nacional brasileiro. Mais do que isso: pode-se observar tal naturalidade do catolicismo no Brasil também na programação profana da mídia. Isso demarca uma constatação: a despeito da reclamação de um silêncio mortal dos media brasileiros para as coisas da Igreja, a rigor, o catolicismo sempre foi constantemente representado e, mais, teve acesso a eles, media, ainda que nem sempre de forma satisfatória para a própria Igreja.

O que se verá neste texto, portanto, é uma breve análise, possibilitada pela organização de informações dispersas, sobre a proximidade entre sistemas midiáticos e de moralidade. Diferentemente do que normalmente é narrado pelas instituições religiosas, todavia, tal proximidade não se dá como uma sucessão dramática de pequenos milagres. Seja pela presença ostensiva de pastores, em canais próprios de rádio e $\mathrm{TV}$, seja por sua presença a partir de aluguel - ou cessão, como ocorreu historicamente no caso do catolicismo - de espaços na mídia secular, a proximidade se dá como indício de que as mitologias forjadas em uma e outra transmissora possuem, com efeito, uma estranha espécie de simbiose.

\section{DEUS PELA MÁQUINA}

De início, uma digressão, necessária, para localizar o título proposto para o artigo: Deus ex machina, deus por meio da máquina. Trata-se de recurso pelo qual, diante de uma situação cênica sem solução, o poeta faz surgir uma entidade supramundana que garanta a unidade dramática. Aristóteles (1992) condenou o recurso que opõe, ao aniquilamento do herói, a perspectiva de uma mudança favorável, antecipada na fala das divindades que se interpolam à ação dramática. Segundo sua doutrina, o deus ex machina atentava contra a verossimilhança e, tal como fizera Platão com a imagem, por a ela imputar a fonte dos enganos, Aristóteles condenou o recurso, por ser esteticamente menor. Há mais do que isso, 


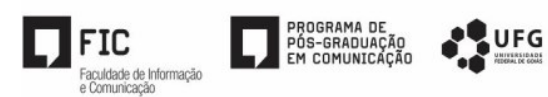

no entanto.

Na poética aristotélica, o deus ex machina era o que os discursos religios os chamam de milagre. Naquele caso, a condenação se dava por um preceito estético: é sempre preferível que, segundo a verossimilhança, as soluções dramáticas sejam encontradas de forma racional. Se vivesse hoje, Aristóteles ficaria confuso e repensaria o seu conceito. Aqui, deus ex machina é um duplo: razão que se sustenta na desrazão. Pois é precisamente este o dilema que estabelece o deus ex machina contemporâneo: o uso racional das formas de expressão e distribuição simbólicas hegemônicas pelas religiões indica a presença material dos media, mas em nome do milagre cotidiano, do inefável que forja nossas vidas na insegurança de nossa modernidade, de cujo drama nós necessitamos - drama que se mostra como aparição mágica da matéria transformada em espírito. Em outras palavras: o acesso das religiões, inclusive as católicas, aos meios de comunicação - deve-se insistir: meios de produção e distribuição simbólica - não tem nada de miraculoso. Pelo contrário, trata-se de um privilégio, dado ou conquistado, pouco importa, compartilhado pelos reais proprietários dos meios de produção - simbólicos e não simbólicos.

Por outro lado, porém, é preciso lançar mão do discurso miraculoso, porque efetivamente os meios de comunicação estabelecem uma relação de milagre com o cotidiano. Em uma sociedade que substitui o sentimento de liberdade pelo de medo, a religião midiática resolve o drama pelas aparições mágicas através dos meios que unem os indivíduos isolados. O deus ex machina das religiões, porém, não consegue sair da desgraça cotidiana. Se, pela magia da imagem (imago), por sua aparição fantasmagórica, há uma promessa de apaziguamento, a paz logo se dissipa no mesmo cotidiano, que permite apenas uma transcendência: a promessa da magia que a mercadoria traz consigo. De qualquer maneira, deus ex machina: no nosso caso, ao menos por ora, nos interessa apenas o milagre que permite o milagre - a apropriação dos meios de comunicação, que diz quem e o que poderá ser dito, transmitido, consumido.

Obviamente, há sutilezas que diferenciam a apropriação dos meios e seu uso pela ética católica e a não católica, especialmente as religiões urbanas neopentecostais, chamadas e reconhecidas propriamente como televangelizadoras. Isso será aprofundado adiante. Agora, nos interessa enxergar de perto a ação do deus ex machina: como os milagres são possibilitados graças ao acesso e a presença das religiões na mídia. Aqui, o foco será a realidade brasileira, mas, como é óbvio supor, é mister compreendermos sua aparição naquele que é considerado o berço da televangelização: os EUA. Veremos ainda que os católicos 
brasileiros não teriam muito do que reclamar se se observa apenas o acesso aos meios de comunicação.

\section{O ESPÍRITO SOBRE AS CASAS}

Os milagres não cessam de acontecer na realidade brasileira: entre ondas sobre telhados, entre satélites - em rádios e sobretudo, dada sua força, em TVs. Dados da Agência Nacional de Telecomunicações - Anatel - apontam para um crescimento, de todo percebido, do controle dos meios de comunicação social por grupos religiosos. A evangelização pela rádio é bastante conhecida e, como veremos, a própria tecnologia de comunicação tem seu nascimento vinculado à televangelização, nos EUA. Até 1995 - ano do emblemático e amplamente explorado advento do "chute na santa"3 -, a Igreja Católica no Brasil não se aventurava verdadeiramente pela TV - tinha, ao contrário, uma posição bastante crítica em relação a ela, como, a despeito de sua crescente participação e controle de canais de televisão, ainda tem. Essa resistência precisa ser compreendida desde uma instituição sabidamente complexa e não homogênea. De qualquer maneira, é possível verificar em relação à TV uma ambiguidade que, como veremos, é plausível, haja vista a propriedade de transmissão e recepção simbólica. Isso não acontecia com a rádio, todavia - talvez pela proximidade entre as formas de transmissão: multimilenária, a Igreja Católica, religião da palavra e da escrita, se fez na oralidade. Há, portanto, um reconhecimento entre as mídias, em relação à rádio.

Convênios com o governo brasileiro, nas décadas de 1950 e 1960 principalmente, para educação a distância, tornaram possível um quase monopólio da Igreja Católica em concessões de rádio. Cessados os convênios de educação a distância com o governo brasileiro, as rádios educativas católicas continuavam a operar seu ensinamento - agora, se ensinava a palavra de Deus.

Pouco a pouco, sobretudo na década de 70 , diversas organizações religiosas nãocatólicas conseguiram concessões de rádios - muitas "educativas". Atualmente, estudos apontam para uma verdadeira simbiose entre religião e rádio. Os dados da Anatel, porém, não permitem que se verifiquem, com exatidão, as concessões - e estamos tratando aqui apenas de rádios com outorgas garantidas oficialmente - ligadas a grupos religiosos: a maioria das concessões está em nome de pessoas físicas e pouquíssimas ligadas diretamente a igrejas ou a

\footnotetext{
${ }^{3}$ Na madrugada de 12 de outubro de 1995, dia de Nossa Senhora Aparecida, padroeira do Brasil, um então obscuro pastor da Igreja Universal do Reino de Deus, Sérgio Von Helder, em um horário de pouca audiência, proclama que aquela estátua, da santa, à sua frente era senão um pedaço de gesso. O caso ganhou uma inesperada repercussão - graças à desproporcional, nos dias que se seguiram, cobertura da mídia brasileira, principalmente a Rede Globo de Televisão.
}

Comun. \& Inf., Goiânia, GO, v. 18, n. 2, p. 53-72, jul./dez. 2015 
associações devocionais. Estima-se, no entanto, que pelo menos $30 \%$ das concessões de rádios FM e AM estejam de posse de grupos religiosos. Entre as rádios comunitárias, segundo estudo dos professores Venício Lima e Cristiano Aguiar Lopes (LIMA; LOPES, 2007), das 2205 rádios comunitárias autorizadas pelo Ministério das Comunicações brasileiro, 120 $(5,4 \%)$ estavam diretamente vinculadas a grupos religiosos. O estudo revela que, das 120 rádios comunitárias religiosas, 69,2\% eram ligadas à Igreja Católica; 27,5\% a igrejas nãocatólicas de diversos matizes; duas a grupos católicos associados a grupos não-católicos - sem precisar de qual tendência; uma rádio a grupo de umbanda e outra a grupo ligado ao espiritismo kardecista. ${ }^{4}$ Há ainda as rádios que funcionam sem a concessão do Estado brasileiro. Estimativas apontam para 10 mil rádios não legalizadas, das quais, ao menos 50\% estão nas mãos de grupos religiosos. ${ }^{5}$

De qualquer forma, há uma clara predominância do catolicismo em relação ao controle da radiodifusão brasileira. A Rede Católica de Rádios é formada por 215 concessões de rádios $\mathrm{FM}, \mathrm{AM}$, ondas curtas e ondas tropicais. Esse contingente representa, segundo os dados da Anatel, aproximadamente 5\% de todas as concessões de rádios no País, o que a torna a maior concessionária de radiodifusão entre os grupos religiosos.

Se a relação entre Estado e Igreja Católica garante a supremacia nas ondas radiofônicas, o mesmo não pode ser dito em relação à TV - não em razão da ausência de disposição católica em conseguir canais, mas muito pelas restrições que a própria Igreja se impôs em relação ao medium. Muito se disse sobre a timidez católica em relação à busca por controle de audiovisual, enquanto suas concorrentes, sobretudo as neopentecostais, criaram verdadeiros impérios televisivos. A década de 1990 marca a reação católica. Não se pode dizer, embora tudo leve a crer que se trata de uma reação concorrencial, que as lideranças eclesiásticas e movimentos religiosos católicos tenham sido impelidos exclusivamente em virtude da crescente perda de fiéis para agremiações não católicas, observada década após década. De qualquer forma, a Igreja, impelida ou não pela concorrência no mercado religioso,

\footnotetext{
${ }^{4} \mathrm{O}$ estudo, desenvolvido em pareceria com o Instituto para o Desenvolvimento do Jornalismo, ligado à Sociedade Brasileira para o Progresso da Ciência, mostrou ainda o "coronelismo eletrônico" em relação às rádios comunitárias vinculadas a políticos profissionais: $50,2 \%$ das outorgas foram destinadas a eles. Como muitas delas têm dupla vinculação - político e religioso -, estima-se que os canais "comunitários" são predominantemente de proselitismo político e/ou religioso. O interessante no estudo é perceber como há uma relação umbilical entre concessões de canais eletrônicos de comunicação, Estado brasileiro e grupos religiosos, com nítida vantagem para grupos católicos.

${ }^{5}$ ATHAYDE, 2006. A reportagem da CartaCapital revela também que, das rádios sem concessão, cerca de $20 \%$ são vinculadas a políticos - e há ainda duplicidade de vínculo, entre políticos religiosos ou religiosos políticos, com clara vantagem para grupos católicos. Assim, a rede de comunicação eletrônica brasileira está muito evidentemente colonizada por grupos religiosos.
}

Comun. \& Inf., Goiânia, GO, v. 18, n. 2, p. 53-72, jul./dez. 2015 
entrou com força nos anos 1990 pelo controle da TV. Isso é um sinal de que a televisão é o aparelho que, a despeito da alegada agilidade do rádio e, segundo a hipótese levantada atrás, pela proximidade em relação ao veículo preferencial católico, a oralidade, certamente mais promove o impacto cotidiano pretendido. É evidente: a TV ainda monopoliza a produção de sentido do mundo contemporâneo - e isso foi, ainda que tardiamente, percebido pela Igreja Católica. Por essa razão, não obstante a importância do sistema radiofônico para o que se chama de telerreligião, este texto se baseia na análise do fenômeno televisivo da religião: trata-se de tecnologia social central para a sociabilidade.

Desde 1989, quando a Igreja Universal do Reino de Deus, do bispo-empresário Edir Macedo, comprou a Rede Record de Televisão, o fenômeno só faz crescer. A Igreja Universal é concessionária de 79 emissoras geradoras - 19 apenas da "cabeça de rede" Record - e 47 repetidoras. A Igreja Católica - grupos ou pessoas a ela ligados - tem 12 emissoras em funcionamento, mas ao menos 14 outras concessões já estão concedidas pelo governo federal brasileiro. O aparelho midiático católico possui ainda 178 repetidoras. Até a inauguração da Rede Vida, em 1995, a Igreja Católica tinha só uma emissora, a Sudoeste, no interior do Paraná, da Ordem dos Frades Menores. Em 1998, entraram no ar a primeira geradora da TV Canção Nova (hoje são quatro) e a TV Horizonte, da Arquidiocese de Belo Horizonte. Um ano depois, surgiu a TV Século 21, cuja proprietária é a Associação Senhor Jesus, liderada pelo padre estadunidense Eduardo Dougherty. Radicado no Brasil desde a década de 1970, o padre jesuíta é um dos nomes de destaque da Renovação Carismática Católica. Em 2002, surgiu a TV Nazaré, da Arquidiocese de Belém, à qual se seguiram a TV Educar, em Ponte Nova, Minas Gerais, em 2003, e a TV Imaculada Conceição, em Campo Grande, em 2004. Em 2005, foi lançada a TV Aparecida, com a pretensão de ter cobertura nacional. Há ainda a TV Alvorada, pertencente à Diocese de Parintins, Amazonas; e a TV Fraternidade, que, além de programação própria, é retransmissora das redes católicas Vida, Canção Nova e Século XXI, no Rio Grande do Sul. Entre as TVs católicas, apenas a Canção Nova e a Imaculada Conceição são mantidas exclusivamente por um sistema agressivo de arrecadação junto a fiéis. Por isso, dispensam a venda de espaço publicitário - salvas, e não raras, as mercadorias ligadas às próprias comunidades religiosas: respectivamente a Fundação João Paulo II e a Fundação Padre Kolbe.

Além dos inúmeros espaços pagos em diversas emissoras comerciais, outras instituições religiosas, quase todas elas pertencentes às chamadas agremiações neopentecostais, de inspiração estadunidense (CARRANZA, 2000), detêm outorgas de TV de 
norte a sul do País, sejam em sinal aberto, geralmente em sistema UHF, com recepção por satélite, sejam disponibilizando-o em sinal para assinatura. A Igreja Assembleia de Deus mantém a TV Boas Novas, com cobertura via satélite e programação completamente voltada para a evangelização; a Rede Gospel, da Igreja Apostólica Renascer em Cristo, dos bispos Estavam e Sônia Hernandes, também voltada para evangelização, tem sinal aberto, em UHF, e mantém contratos com operadoras de TV a cabo para sua transmissão; e a Rede Gênesis pertence à comunidade evangélica Sara Nossa Terra. Diferentemente de suas irmãs, a Gênesis, fiel ao seu slogan "A unção está no ar - Entretenimento cristão para toda a família", promete - e cumpre - uma programação que ultrapassa as tradicionais pregações evangélicas. Oferece programas infantis, filmes, jornalismo - além, é claro, de cultos, leituras bíblicas e palestras proselitistas. A Rede Internacional de Televisão (RIT) é de propriedade da Igreja Internacional da Graça de Deus, comandada pelo missionário Romildo Ribeiro Soares, o R.R. Soares. Depois de adquirir espaços em redes de TV aberta - e causar um desconforto entre as afiliadas, ${ }^{6}$ o missionário montou sua própria TV, em 1999, para, em 2002, promover sua expansão. Atualmente, a Rede Internacional de Televisão é composta por oito emissoras e mais de 62 canais de Rádio e TV. A RIT pode ser sintonizada, em sinal aberto, por UHF, ou nas TVs a cabo.

Entre as televisões ligadas às religiões protestantes históricas, há ainda a Rede Super, mantida, desde 2002, pela Igreja Batista da Lagoinha, em Belo Horizonte. Transmitida por sinal fechado e também em sinal aberto, em UHF, a Rede Super, antes limitada ao entorno da capital mineira, atualmente tem alcance nacional. Entre os protestantes restauracionistas, há a TV Novo Tempo, controlada pelo Sistema Adventista de Comunicação. No início da década de 1990, os Adventistas receberam concessão do Ministério das Comunicações brasileiro, como TV Educativa e Cultural, afiliada, desde o Vale da Paraíba paulista, à TVE - atualmente TV Brasil - e TV Cultura de São Paulo. Desde 2006, a TV Novo Tempo, após a concessão de outorga do governo federal, gera programação própria e transmite por sinal aberto UHF para vários estados, e em sinal fechado, a cabo.

A Legião da Boa Vontade, organização parareligiosa liderada pelo também missionário José Paiva Neto, que, como o missionário RR Soares, se notabilizou por comprar

\footnotetext{
${ }^{6}$ No início de 2002, R.R. Soares, segundo notas da imprensa da época, aproveitando a crise do mercado publicitário, ofereceu R \$2 milhões por mês à TV Bandeirantes para ocupar, diariamente, o horário "nobre" das $20 \mathrm{~h} 30$ às $21 \mathrm{~h} 30$ (cf. JIMENEZ, 13/12/2002). Mais tarde, as TVs afiliadas à rede ensaiaram uma rebelião contra a decisão - tratava-se de um horário nacional (cf. CASTRO, 07/01/2003). A "rebelião" não durou muito tempo. Depois de um boicote, um acordo de bastidores, não divulgado, colocou a casa em ordem. O Show da fé, programa do missionário, ainda hoje ocupa o horário semelhante àquele que provocou a revolta - mesmo depois de ter havido recuperação do mercado publicitário.
}

Comun. \& Inf., Goiânia, GO, v. 18, n. 2, p. 53-72, jul./dez. 2015 
espaços na grade de programação de televisões comerciais abertas, também adquiriu seu próprio canal em 2000. Com o slogan "A TV que faz bem", a Boa Vontade TV transmite em sinal aberto, além das TVs pagas, para o país inteiro, e também para os EUA, México e Canadá, com cobertura nacional, e para Portugal, Argentina, Paraguai e Uruguai. Há, ainda, funcionando no Brasil desde 2007, a TV Enlace (com o slogan "Uma imagem que vem do alto"), surgida nos anos 1980 em Porto Rico e ligada ao movimento cristão neo-pentecostal Enlace juvenil. Segundo seus prospectos, sua programação alcança mais de 90 países e está presente com produtora em 23 deles. Prometeu, com sua chegada no Brasil, fazer o que realizou em território estadunidense e, com efeito, as possibilidades de sucesso da TV Enlace em terras brasileiras podem ser prodigiosas, haja vista as estratégias profissionais adquiridas em terras estadunidenses. Não deixa de ser interessante observar, a partir da experiência da Enlace, um fenômeno de inversão: a telerreligião teve seu nascimento a partir de grupos neopentecostais estadunidenses - em que muitos autores enxergam traços do fundamentalismo cristão, advindo dos movimentos carismáticos de renascimento (ASSMANN, 1986; SILVEIRA CAMPOS, 2004; GOMES, 2004). ${ }^{7}$ Porém, essa importação ocorre em um momento quando os grupos religiosos nacionais já colonizavam a mídia eletrônica e se preparam, e não raro têm conseguido, para uma ofensiva de internacionalização. É interessante observar que a lógica da mercantilização religiosa via mídia eletrônica, especialmente a TV, foi completamente aplicada em terras brasileiras - como ademais, na América Latina. Assim, a promessa de crescimento da TV Enlace não se daria em função de sua tecnologia de transmissão, mas porque encontra aqui um terreno já bastante fertilizado pelas suas concorrentes brasileiras. Com isso, quer-se acreditar que o mercado telerreligioso, longe de ser limitado, é a condição para a entrada de vez na modernidade capitalística hegemônica.

\footnotetext{
${ }^{7}$ Karen Armstrong (2001), no esforço para a compreensão do fenômeno fundamentalista entre cristãos, judeus e muçulmanos, aponta para uma díade logos x mythos. Segundo ela, tradicionalmente, as religiões tendem ao equilíbrio entre uma postura racional de explicação da vida e outra, fundada na pura emoção. Sempre houve, diz Armstrong, em todas as religiões abraâmicas, monoteístas, movimentos de reavivamento da fé imediata, que caracterizariam o fundamentalismo. Tais movimentos indicam ora uma falência da racionalidade em vigor - e de qualquer forma assentada no logos -, ora, como resultado de tal falência, uma revolta conservadora de líderes carismáticos em busca de uma fé além daquela sustentada pelas religiões. A autora se refere, é claro, àquilo que o pensamento ocidental caracterizou como uso da razão versus a emoção. Há que se discutir, no entanto, a pertinência desse modelo para a compreensão do fenômeno religioso, ao menos em sua versão contemporânea, hegemonicamente telerreligiosa. Aqui, há mais razão onde houver mais emoção; o mito é logocentrado. Se não se pode dizer que a colonização universal praticada pelo capital tenha o transformado em uma verdadeira religião - ou, como disse Marx (apud LÖWY, 2000, 16), o progresso capitalista é um "monstruoso deus pagão que só quer beber o néctar nos crânios dos mortos" -, não se pode negar que sua colonização alcançou lugares insuspeitos outrora, como a própria transcendência. O capital criou, aliás, a sua própria máquina transcendental, que tem no consumo capitalístico o seu serafim, em cuja fonte bebem as telerreligiões.
}

Comun. \& Inf., Goiânia, GO, v. 18, n. 2, p. 53-72, jul./dez. 2015 
Por fim, uma TV espírita: a TV Mundo Maior, uma emissora da Fundação Espírita André Luís, no ar, via satélite, em sinal aberto, desde 2006, tem uma programação completamente voltada para o proselitismo. Seus prospectos dizem ser a Mundo Maior voltada para "princípios cristãos, em especial por meio da prática da solidariedade e assistência social. Engajada no contexto de responsabilidade social tem como missão contribuir para a construção de uma sociedade digna ligada às práticas de atos saudáveis." Ou seja, trata-se de, como suas irmãs - católicas, protestantes históricas e neopentecostais -, servir de contraponto para o que elas, as detentoras de canais de TV religiosos, chamam de mídia secular: a mídia comercial, em geral. A despeito da clara contradição - uma vez que o princípio básico da telerreligião é o marketing religioso -, é mister admitir que se constituem, os canais de TV religiosos, de contraponto moral para a mídia comercial secular: o valor, aqui, é o comunitarismo, embora, como já muito se explorou (entre muitos outros, MARIANO 1999; CAMPOS, 2004; e, a respeito da moralidade dos carismáticos católicos, PRANDI, 1997), valores individualistas lhes sejam caros. Nem mesmo aí existem elementos excludentes, todavia: a moralidade individualista coincide com a outra, gregária, na nova religião. Eis então a diferença na abordagem aqui proposta: deve-se ir além das estruturas de leitura, segundo as quais se procura observar semelhança entre a lógica do capital e a novíssima lógica religiosa - a telerreligião. O que está em jogo, e que obviamente é perpassado pela mercantilização da religião, é o que podemos chamar de metafísica da subjetividade: não há contradição entre religião e capitalismo, ainda que sejam, sistemas midiáticos seculares e religiosos, contrapontos entre si, especialmente em relação à mídia católica. É preciso olhar para as estruturas liquefeitas de um e outro sistema, como ademais para a própria materialidade imaterial do capitalismo contemporâneo. Só assim é possível compreender como mito e racionalidade coincidem para forjar humanos dóceis. Para tanto, é necessário adentrar na teogoniadatelerreligião católica, compreendermos de que forma há uma relação, digamos, fraterna entre religião e mídia eletrônica desde o surgimento desta, nos EUA.

\section{A DIÁSPORA}

Se as décadas de 1970 e sobretudo 1980 foram marcantes para a evolução da igreja eletrônica no Brasil; e se, como visto, a década de 90 pode ser considerada o marco zero, inclusive pela reação católica no setor da telerreligião no País, essa história está assentada em décadas atrás. Nem mesmo o fenômeno dos padres cantores católicos que visitam, com 


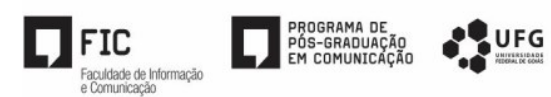

maestria, o star system midiático, a ponto de terem sido um dos sustentáculos dos programas de entretenimento da mídia secular e hoje serem ser um dos pilares da indústria fonográfica brasileira em crise, é tão novo.

Como vimos, até os anos 1960, a Igreja Católica mantinha um sistema de rádios educativas - cuja concessão foi fruto de convênio com o governo brasileiro para educação a distância. Mas tratava-se de uma experiência, até então, de educação a distância. Somente depois, já na década de 1970, as emissoras, ainda mantendo o caráter educativo e cultural, se abriram para o proselitismo. No caso das agremiações não católicas, o primeiro programa evangélico brasileiro de que se tem notícia data de 1943: A voz da profecia, com direção do pastor adventista Roberto Rabello, escolhido para ser orador oficial do programa para a língua portuguesa. O programa era produzido desde 1929, em Los Angeles, pelo pastor H.M.S. Richards. Em 1943, 52 programas foram gravados nos EUA e enviados, em discos de vinil, para o Brasil. No dia 23 de setembro daquele mesmo ano, 17 emissoras de rádio das principais cidades brasileiras transmitiram $A$ voz da profecia.

Na TV brasileira, o sistema adventista também foi pioneiro. Data de 1962 o primeiro programa pentecostal televisionado no País - é preciso considerar apenas os programas declaradamente proselitistas. O Fé para hoje, transmitido pela TV Tupi na década de 60, durante muitos anos esteve presente na grade de programação da TV Gazeta - substituída atualmente pela Igreja Universal - e hoje transmitida pela TV Novo Tempo, propagando em sinal aberto, com alcance nacional, e também na TV fechada. Não obstante, a força da produção local dos televangelistas - salvas raras exceções - era bastante limitada. Até os anos 1980, eram muitos os programas de televisão pentecostais estadunidenses - entre eles, os mais assistidos eram os de Rex Humbard - Alguém ama você - e de Pat Robertson - o Clube 700. Os cultos de Jimmy Swaggart, todavia, eram os programas mais populares - razão por que ele pode ser considerado o mais influente entre os televangelistas brasileiros (ASSMANN, 1986; SANTANA, 2005; FONSECA, 2006).

A partir de meados dos anos 1980, a produção brasileira evangélica para a TV se tornou independente e passou a ocupar espaços em redes nacionais. Os primeiros e mais conhecidos televangelistas brasileiros foram R.R Soares, Nilson Amaral Fanini, Edir Macedo e Estevam Hernandes.

Nilson Fanini, pastor batista, produziu e apresentou, nos 1970, o programa Reencontro, veiculado pela TV Educativa do Rio de Janeiro e retransmitido nacionalmente em sua versão radiofônica. Além do Brasil, o programa, depois de consolidado, alcançou a 
África do Sul, o Paraguai e os EUA. A estratégia de exportação de conteúdo também foi importada dos televangelistas estadunidenses. Mais tarde, suas relações com a ditadura militar brasileira foram muito bem aproveitadas. Em 1983, o pastor Fanini recebeu das mãos do general João Batista Figueiredo a concessão da TV Rio, que manteve até ser vendida para Edir Macedo, 15 anos depois.

Outro pop star televangelista brasileiro foi - e continua sendo - Romildo Ribeiro Soares, da Igreja Internacional da Graça de Deus. R.R. Soares é o pentecostal há mais tempo no ar: desde os anos de 1970 - inicialmente pela TV Record e depois por diferentes emissoras -, possui programa veiculado em horário pago na Bandeirantes, CNT, Rede TV e TV Gazeta. Os seus programas diários, em que o missionário está sempre trajado em um impecável terno, têm ênfase na cura e no sucesso econômico-financeiro.

O terceiro pai do televangelismo brasileiro é Edir Macedo, cuja história foi por ele próprio contada em uma biografia, e cuja trajetória foi amplamente estudada, o que nos desobriga a aqui fazê-lo (entre muitas referências, ver CAMPOS, 2004; GOMES, 2004; ORO, CORTON \& DOZON, 2003).

Há ainda o caso dos missionários Estevam e Sônia Hernandes, da Igreja Renascer em Cristo. Além das encrencas em que se meteram,${ }^{8}$ tentaram e quase conseguiram comprar a extinta TV Manchete. Em janeiro de 1999, a Fundação Renascer, da Renascer em Cristo, assinava um contrato de parceria com Rede Manchete de Televisão. A R.G.C. Produções Ltda. (produtora pertencente à fundação), que fazia os programas da Igreja Renascer exibidos na Manchete, passava a dividir a responsabilidade pela produção, operacionalização e comercialização das cinco emissoras que compunham a rede, sob pagamento mensal de $\mathrm{R} \$$ 4,8 milhões, por 15 anos. Segundo o bispo Antonio Carlos Abbud, sócio do missionário Estevam Hernandes, não se tratava da compra da rede, mas de uma sociedade (FOLHA DE S.PAULO, 5 de janeiro de 1999). No final daquele mesmo mês, contudo, o governo brasileiro julgou ilegal o acordo e exigia que a Fundação Renascer assumisse tudo - a programação e as dívidas. $\mathrm{O}$ tal acordo era uma jogada do missionário para que sua fundação não assumisse a dívida da TV. Depois de idas e vindas, ameaças de Hernandes e contra ele, finalmente, em

\footnotetext{
${ }^{8}$ Uma série de reportagens da revista Época, do grupo Globo, que se inicia em 2002 e intitulada O lado sombrio da Renascer, denunciava os "golpes, contratos irregulares e processos" que "fazem parte do dia-a-dia de uma das igrejas que mais crescem no Brasil” (cf. DANTAS, Época, 20/05/2002). As notícias de irregularidades continuaram e o Ministério Público os indiciou por lavagem de dinheiro, estelionato, formação de quadrilha e falsidade ideológica, até que, no final de 2007, o casal foi preso nos EUA, sob a acusação de tentarem entrar no país com dinheiro não declarado. Em 2008, a justiça brasileira congelou os bens do casal, cuja fortuna foi estimada, pelo próprio Ministério Público, em aproximadamente R $\$ 130$ milhões - conseguidos com a mais pura ação evangélica.
}

Comun. \& Inf., Goiânia, GO, v. 18, n. 2, p. 53-72, jul./dez. 2015 
abril de 1999, Amílcare Dallevo Júnior, proprietário da TeleTV e da TV Ômega, adquiriu a TV Manchete e a transformou em RedeTV! - a emissora comercial com a segunda maior programação telerreligiosa, segundo dados da Ancine - Agência Nacional de Cinema brasileira. ${ }^{9}$ Mais uma vez, entre os negócios e Deus, o lance da venda e transformação da Manchete em RedeTV! mostrou que não há excludência entre eles. Quanto à Igreja Renascer em Cristo, depois do fracasso no negócio de uma rede de TV pronta, os missionários Hernandes montaram a Rede Gospel de TV. Em função dos escândalos em que se envolveram, o Ministério das Comunicações brasileiro cassou algumas concessões de rádio e de retransmissoras de TV (FOLHA DE S.PAULO, 31/01/2007). Dessa vez, não houve como Deus operar milagres.

\section{CRESCEI E MULTIPLICAI-VOS}

A Igreja Católica e sua investida no sistema televisivo é narrada como uma história de milagres ${ }^{10}$. A primeira incursão católica pela TV - sem contar a naturalidade da presença de católicos na programação televisiva brasileira - data do início dos anos 70, com a experiência dos Freis Franciscanos Capuchinhos, do Rio Grande do Sul, que fundaram e mantiveram a TV Difusora, em Porto Alegre, como emissora comercial, com alguns programas religiosos, e a TV Pato Branco, no Paraná. A experiência pioneira durou até 1980, quando, em dificuldades, os Capuchinhos venderam as emissoras. Parecia que os milagres cessariam. Mas apenas parecia. Eles retornaram, com força, na década de 90.

Milagre é, aliás, a explicação dada para a criação e consolidação das duas maiores redes católicas de Televisão: a Rede Vida e a Canção Nova. Os prospectos da Rede Vida,

\footnotetext{
${ }^{9}$ Um comparativo dos dados da Ancine, de 2009 a 2014, indicam a seguinte evolução da distribuição da programação religiosa de TV aberta no Brasil. Em 2009, a TV CNT tinha 30\% de sua programação ocupada por programas religiosos, seguida da RedeTV!, com $22,8 \%$, Record, com 17\%, Band, com 16,8\% e TV Gazeta, com $11,6 \%$. A Rede Globo e as públicas TV Brasil e TV Cultura tinham menos de 1\% de sua grade ocupada com programas religiosos. Em 2014, a GNT aumentou para 74,3\%, seguida da RedeTV!, que quase dobrou a exposição religiosa em cinco anos, para $44,4 \%$ de sua grade ocupada por programas religiosos; na Rede Record houve um aumento da presença religiosa para $23,8 \%$ do tempo de sua programação, seguida pela TV Gazeta, com 15,8\%, tomando o lugar da Band, que ainda, apesar do decréscimo, mantinha $15,1 \%$ de programação religiosa. A Rede Globo e a pública TV Cultura mantiveram um índice de menos de 1\%, mas a TV Brasil saltou para 2,4\%de sua programação ocupada por programas religiosos. Esses números já seriam interessantes por si mesmos - mas a Ancine, em 2009, sintomaticamente, enxergou uma relação entre a telerreligião e televenda isso considerando é claro apenas os programas que claramente versam sobre religião ou vendem de forma explícita produtos. Segundo esses dados, $25 \%$ da programação da TV aberta brasileira são feitos da somatória entre programas religiosos e de televenda. Em 2014, o levantamento cuidou de separar os gêneros, mas, apenas para efeito de comparação, o número da somatória teve um ligeiro aumento, para 26,2\%.

${ }^{10} \mathrm{O}$ histórico a seguir se limitará às redes de televisão católicas: a Rede Vida, A TV Canção Nova, a TV Século XXI e a TV Aparecida. Serão, portanto, deixadas de lado as TVs católicas isoladas ou retransmissoras das cabeças-de-rede.
}

Comun. \& Inf., Goiânia, GO, v. 18, n. 2, p. 53-72, jul./dez. 2015 
nascida em 1995, assim narram sua trajetória:

Um jornalista de Barretos, interior paulista, terra da Festa do Peão, montou a maior rede católica de televisão do mundo. Um ato de fé que muitos classificam como um verdadeiro milagre.

- Sim, é o milagre da normalidade - responde o jornalista João Monteiro de Barros Filho, filho de peão de boiadeiro, nascido no dia 5 de novembro de 1938. A idéia de formar a REDEVIDA de Televisão nasceu durante o governo do presidente José Sarney (BELTRAMIM, 2013).

Eis precisamente o milagre: a normalidade. A Igreja Católica assistiu um tanto passiva ao desdobramento e avanço das agremiações não católicas pelo mundo da TV. Quando ocorreu o marco zero, o evento do chute na santa, o catolicismo já começava a se movimentar em busca do terreno perdido. Mas tal evento foi, de fato, determinante para o avanço católico. E os milagres tornaram a acontecer - milagres da normalidade. Como na década de 1950, quando Igreja e Estado brasileiro firmaram acordos que deram à instituição religiosa inúmeras concessões de rádio, que depois formariam a Rede Católica de Rádio, agora as concessões também começavam a aparecer. Não que as concessões para as chamadas seitas, geralmente pentecostais, não acontecessem também por essa relação tão estreita entre grupos religiosos e Estado. A questão aqui está justamente na naturalidade do catolicismo brasileiro. Em pouco mais de 15 anos, a Igreja Católica, que se movimentou apenas em meados dos 1990, se vê transformada em um império telemidiático, mantido pelo INBRAC Instituto Brasileiro de Comunicação Cristã, com a presidência de João Monteiro de Barros Filho

Atualmente, é da Rede Vida tem o segundo maior número de outorgas de repetição de sinal do Brasil: está em 500 cidades brasileiras e tem mais de 500 outorgas - números superiores até aos da própria Rede Globo, uma vez que, na maioria dos Estados e regiões, a TV Globo é retransmitida por parceiros/afiliados. Em termos absolutos, a Rede Vida só perde para a TV Canção Nova, como ver-se-á adiante. Seja como for, a Rede Vida é um portento. Cerca de $35 \%$ da sua programação é religiosa, composta por missas, reza do terço e reflexões, e destina-se à evangelização, alguns patrocinados por anunciantes. Os outros $65 \%$ da grade de horários, e seguindo o slogan, $O$ canal da família, são avessos a conteúdos agressivos. São veiculados desde programas infantis, passando pelo futebol, filmes - de caráter religioso e, acrescentemos, desde que não estejam condenados pelo índex do Vaticano - e musicais. Sua programação conta com algumas muitas inserções comerciais - ou melhor, com televendas. Essa é a fonte de receita para a manutenção da TV.

Bem diferente é a manutenção da TV Canção Nova, feita exclusivamente por doações de seus sócios - responsável por cerca de $70 \%$ da receita - ou por venda de produtos Comun. \& Inf., Goiânia, GO, v. 18, n. 2, p. 53-72, jul./dez. 2015 
exclusivos da comunidade religiosa, anunciados pela TV. A manutenção da rede de comunicação é um verdadeiro milagre: em 2007, a receita chegou a R\$127 milhões, arrecadados apenas com aquele expediente. Para tanto, o Sistema Canção Nova de comunicação mantém um agressivo programa de arrecadação, denominado Dai-me almas. A captação pode ser acompanhada pela página da Internet, que mantém média mensal de mais de quatro milhões de acessos. No site da TV na internet, há um ícone com o título do programa de doação, em que um gráfico mostra o percentual da necessidade de fundos da rede que já foi satisfeita pelas doações. Há ainda outros programas, como o Juntos Somos Mais, que incentiva novos sócios e transmite encontros de arrecadadores; o Deus Proverá, que presta contas dos gastos, necessidades e conquistas da Comunidade Canção Nova; e o Momento de Adoração, dedicado especialmente para as intervenções dos sócios. O Sistema Canção Nova é mantido pela Fundação João Paulo II - entidade sem fins lucrativos, caracterizada como uma obra que subsiste pela Divina Providência. Trata-se efetivamente de um milagre.

Milagre, aliás, é a palavra usada pelo criador da Comunidade Canção Nova - voltada para a evangelização pelos meios de comunicação social -, o carismático Padre Jonas Abib, para se referir à própria criação da comunidade religiosa e seu poderio midiático (CHALITA, 2006). A TV Canção Nova foi criada em 1989, mas somente em 1997 formou-se a Rede Canção Nova de Televisão com a compra da TV Jornal em Aracaju, até então afiliada à Rede Bandeirantes, transformada em TV Canção Nova Aracaju e responsável pela geração da programação para o Nordeste brasileiro. Em 2007, com apenas dez anos de formação da rede, a TV Canção Nova estabeleceu-se como a maior emissora de televisão católica do Brasil e ultrapassou a até então líder no segmento, a Rede Vida. Desde setembro de 2005, a TV Canção Nova chega a todas as regiões da Europa. Recentemente, passou a atingir também os televisores do Oriente Médio, Ásia, África e Oceania, além de transmitir sua programação por webtv, atividade em que foi pioneira. Atualmente, seu sinal é gerado apenas da sede, em Cachoeira Paulista, e em Aracaju, mas mantém geradoras afiliadas em Belo Horizonte, Curitiba, Florianópolis e Brasília. Possui retransmissoras em mais de 300 municípios brasileiros; cobertura em todo o Brasil pela parabólica; e em cerca de 200 operadoras de televisão por assinatura. Isso sim é reação católica à altura - um milagre sem precedentes, só comparável ao poderio alcançado pela Rede Globo de Televisão, sob os auspícios da ditadura militar brasileira.

Talvez, entre as Redes Católicas de TV, a única que não se declara produto de um 
milagre é a TV Século XXI. Nem precisava: o milagre a acompanha desde seu fundador, o padre Eduardo Dougherty, um dos responsáveis, ainda nos anos 1960, por trazer a Renovação Carismática Católica (RCC), dos Estados Unidos para o Brasil. Até então, a Associação Senhor Jesus (ASJ), que trabalha com a evangelização a partir dos meios de comunicação, fundada em 1979, em Campinas, mantinha programas de rádio em diversas estações pelo Brasil. No início dos anos 1980, porém, se anunciava o futuro: a ASJ criou uma produtora de televisão especializada em programas dramatúrgicos.

Em 1999, enfim, foi criada a TV, como específica da Renovação Carismática Católica brasileira - a TV Canção Nova, embora igualmente carismática, tem, segundo seus membros, "carismas próprios" e, por isso, não está associada à RCC. A rede de TV Século XXI faz parte de um grupo de comunicação multimídia construído pela ASJ. Além de caracterizar-se como televisão religiosa católica, a Século XXI é uma das maiores produtoras independentes de programas religiosos e minisséries e, por isso, consolidou-se como núcleo de produção teledramatúrgica, com produtos exportados para países do Leste Europeu, Ásia, África, América Latina, Estados Unidos e Europa. A despeito de obter receita de patrocinadores, a TV Século XXI é mantida pela ASJ, que, por sua vez, é sustentada por milhares de sócios contribuintes espalhados por todo o Brasil e pelo mundo.

Por fim, a caçula entre as redes católicas de TV - ao menos por ora, uma vez que, haja vista a velocidade com que grupos católicos têm investido na tecnologia de comunicação de massa, é plausível prever que, nos próximos anos, novas redes surjam, como que por milagre: a TV Aparecida. Com atraso de dez anos em relação ao evento do chute na santa, a rede católica é a resposta mais evidente à heresia do bispo von Helder: a TV Aparecida, depois de longa luta política nos bastidores para que conseguisse a concessão do Governo Federal, iniciou sua programação em 2005. Segundo o histórico oficial da emissora, "a TV de Nossa Senhora Aparecida não nasceu por acaso. Como tudo o que diz respeito a Nossa Senhora e ao projeto de anunciar Jesus Cristo, a TV foi sonhada há pelo menos 40 anos" (http://www.a12.com/tv-aparecida/institucional/detalhes/historia-tv-aparecida - acesso em 04/06/2015). O projeto de criação de uma TV do Santuário de Aparecida vinha sendo alimentado na década seguinte à criação da Rádio Aparecida, em 1950. “O desejo guardado com carinho até que chegasse a hora certa", diz o prospecto da TV. E continua o relato do milagre: “a 'plenitude dos tempos' chegou a partir do ano 2000”, quando enfim a Fundação Nossa Aparecida, mantenedora do sistema de comunicação dos Redentoristas, entrou com o processo de pedido de concessão e outorga. 
A Ordem dos Redentoristas, fundada em 1732, é especializada em comunicação de massa e, hoje, encarregada de administrar o santuário de Nossa Senhora Aparecida, na cidade de Aparecida. O Santuário de Aparecida é um verdadeiro exemplo de como sistema midiático e eclesiástico não são tecnologias excludentes. Anualmente, o Santuário recebe cerca de oito milhões de fiéis, em romarias ou, num novo mercado emergente e amplamente explorado, no turismo estritamente religioso. A TV Aparecida surgiu para "dar continuidade ao relacionamento com os devotos e romeiros", como salienta o diretor da TV, Padre César Moreira. E, para tanto, contou com o apoio e consultoria de ninguém menos que José Bonifácio de Oliveira Sobrinho, o Boni, o ex-mago da TV Globo e membro do alto clero da TV Brasileira.

A programação da TV Aparecida é predominantemente de caráter religioso, mas também apresenta programas de entretenimento, musicais, de variedade e jornalísticos - cujo desdobramento é um portal digital de notícias religiosas, o A12, uma espécie de avatar de portais seculares como o G1, ligada à Globo, ou o R7, da Record. Com essa programação voltada para a variedade, a direção da TV Aparecida quer atrair patrocinadores e anunciantes - atualmente, a maior parte da receita é conseguida com a comercialização de outros produtos de divulgação religiosa, como livros, revistas e jornais. Um exemplo de como os Redentoristas mantêm o contato com fiéis é a Revista de Aparecida. Com periodicidade mensal e distribuída gratuitamente para os sócios contribuintes da Campanha de Devotos, a revista tem tiragem de quase 500 mil exemplares. O sinal da TV, aberto, em UHF, pode ser sintonizado, via satélite, em todo o território brasileiro, e também em sistema fechado, em operadoras de TV a cabo. Uma história de persistência, articulação política - e fé em milagres, pois, como diz ainda o prospecto no sítio eletrônico da TV, "tudo foi possível porque a presença materna da Mãe Aparecida nunca deixou de abençoar tão importante projeto" (ibidem).

Como se vê, a reação católica à investida midiática na TV dos não católicos teve uma resposta demorada - mas bastante à altura. Isso talvez seja resultado não da reação católica e sua investida no cenário televisivo - talvez seja muito mais resultado de uma compreensão de que tal investida já era esperada e que, tendo acontecido, colocou as coisas em seu devido lugar. É muito plausível: o sistema televisivo brasileiro é naturalmente católico, muito embora, no caso da telerreligião, há uma eficaz aproximação entre católicos e não-católicos, tanto na forma de fazer comunicação, quanto no conteúdo - como se vê pelas práticas para que se consigam concessões públicas de radiodifusão. 


\section{CONSIDERAÇÕES FINAIS}

A sobrevivência do divino como sagrado em uma forma cultural que formatou um outro tipo de sagrado, todavia, não se fez sem uma tensa ambiguidade. Ambiguidade, aliás, talvez seja o sintagma que melhor explique não apenas essa tradução entre sagrados de duas épocas e duas formas culturais transmitidas por maquinários distintos - a Igreja Católica medieval como medium e a mídia burguesa -; ambígua é a própria relação da TV Canção Nova, e ademais do catolicismo midiatizado do século XXI.

Ambíguo foi o nascimento da telerreligião, e especialmente da telerreligião católica no Brasil. Se havia uma compatibilidade tecnológica entre o surgimento dos novos meios eletrônicos de comunicação de massa e a telerreligião, isso só confirma essa relação de ambiguidade na transação entre formas e conteúdos. De um lado, coincidências tecnológicas a parte, a telerreligião estadunidense, hegemonicamente pentecostal e neopentecostal, tinha como proposta o que se convencionou chamar de "teologia da prosperidade". Assim, havia a permanência do sagrado da divindade cristã, mas subsumido ao outro sagrado, o capitalístico, que, desde então, se consolidou, para enfim se desmaterializar completamente no culto ao e como consumo. Eis a ambiguidade: a telerreligião é forma; seu conteúdo é o modo de produção capitalista.

No caso católico, essa ambiguidade é levada ao extremo. Embora haja um consenso sobre a reação católica contra o avanço de neopentecostais em território preferencial do catolicismo - o Brasil e ademais a América Latina -, sempre houve uma relação estreita entre meios de comunicação eletrônicos, desde o seu surgimento em território brasileiro, e a Igreja Católica. Pouco a pouco, o esforço de internacionalização, especialmente dos neopentecostais estadunidenses, que tinham na mídia eletrônica seu púlpito, exigiu da Igreja Católica brasileira uma política mais agressiva de acesso aos meios - mas em nenhum momento houve de fato uma distância entre Igreja e meios. Tampouco em relação ao material simbólico circulante havia dúvida: o Brasil era território católico. Mesmo que, ainda hoje, se ouçam reclamações sobre o silêncio da mídia em relação à Igreja, os grupos econômicos de mídia no Brasil sempre foram quase exclusivamente católicos. Havia, portanto, na luta política midiática, uma supremacia católica nas duas frentes: na material, em que a Igreja detinha facilidades para conquistar concessões de rádio e TV e igualmente facilidades para a montagem de infraestrutura de transmissão; e na imaterial, porque a Igreja, bem ou mal, sempre esteve presente, seja nos informativos, seja nos programas religiosos, seja na teledramaturgia, nos programas transmitidos pela mídia - e assim nas mentes e corações dos

Comun. \& Inf., Goiânia, GO, v. 18, n. 2, p. 53-72, jul./dez. 2015 
brasileiros. Essa aproximação, um tanto natural, entre sistema midiático, sociedade política e sociedade religiosa, proximidade que se aprofunda dia após dia, nos coloca diante de um problema verdadeiramente civilizatório, cujos desdobramentos são imprevisíveis, mas que se torna um desafio se se pensa em valores como autonomia, pluralidade e democracia.

\section{REFERÊNCIAS}

ARISTÓTELES. Poética. São Paulo: Ars Poética, 1992.

ARMSTRONG, K. Em nome de Deus: o fundamentalismo no judaísmo, no cristianismo e no islamismo. São Paulo: Cia das Letras, 2001.

ASSMANN, H. Igreja eletrônica e seu impacto na América Latina. Petrópolis: Vozes, 1986.

ATHAYDE, P. Rádios comunitárias: na onda da política. Revista Carta Capital, São Paulo, 2006.

BELTRAMIM, M. Rede Vida. Disponível em: $<$ http://signisbrasil.org.br/noticias/ver/rede-vida $>$. Acesso em: 27 out. 2015.

BRASIL. Presidência da República. Secretaria de Comunicação Social. Pesquisa brasileira de mídia 2015: hábitos de consumo de mídia pela população brasileira. Brasília: Secom, 2014.

CAMPOS, L. S. Teatro, templo e mercado: organização e marketing de um empreendimento neopentecostal. Petrópolis: Vozes; São Paulo: Simpósio Editora: Unesp, 2004.

CARRANZA, B. Renovação carismática católica: origens, mudanças e tendências. Aparecida: Santuário, 2000.

CASTRO, D. Afiliadas se rebelam contra igreja na Band. Folha de São Paulo, São Paulo, 2003. Disponível em: $<$ http://www1.folha.uol.com.br/folha/ilustrada/ult90u29849.shtml >. Acesso em: 27 out. 2015.

CHALITA, G. Eu acredito em milagres: a história de padre Jonas Abib. São Paulo: Canção Nova, 2006.

DANTAS, E. O lado sombrio da Renascer: golpes, contratos irregulares e processos fazem parte do dia-a-dia de uma das igrejas que mais crescem no Brasil. Revista Época, São Paulo, 2002.

Disponível: < http://revistaepoca.globo.com/Revista/Epoca/0,„EDR759575856,00.html $>$. Acesso em: 27 out. 2015.

FONSECA, A. B. Evangélicos e mídia no Brasil. São Paulo: EDUSF, 2006.

GOMES, P. G. Processos midiáticos e construção de novas religiosidades: dimensões históricas. In:

Cadernos Instituto Humanas Unisinos, 8. ed., p. 6-10, 2004.

JIMENEZ, K. Band vende horário nobre a evangélicos. Estadão, São Paulo, 2002. Cultura. Disponível em: < http://cultura.estadao.com.br/noticias/geral,band-vende-horario-nobre-aevangelicos,20021213p6705> . Acesso em: 28 out. 2015.

LIMA, V. A.; LOPES, C. A. Rádios comunitárias: coronelismo eletrônico de novo tipo (1999-2004) - as autorizações de emissoras como moeda de barganha política. São Paulo: Observatório da Imprensa; PROJOR, 2007. Mimeografado

Comun. \& Inf., Goiânia, GO, v. 18, n. 2, p. 53-72, jul./dez. 2015 
LÖWY, M. Guerra dos deuses: religião e política na América Latina. Petrópolis: Vozes, 2000.

MARIANO, R. Neopentecostais: sociologia do novo pentecostalismo no Brasil. São Paulo: Loyola, 1999.

ORO, A. P.; CORTEN, A.; DOZON, JP. (Orgs.). Igreja Universal do Reino de Deus: os novos conquistadores da fé. São Paulo: Paulinas, 2003.

PRANDI, R. Um sopro do espírito: a renovação conversadora do catolicismo carismático. São Paulo: Edusp; Fapesp, 1997.

SANTANA, L. K. A. Religião e mercado: a mídia empresarial-religiosa. Revista de Estudos da Religião, São Paulo, n. 1, p. 54-67, 2005. Disponível em:

http://www.pucsp.br/rever/rv1_2005/p_santana.pdf. Acesso em: 28 out. 2015.

SCIARRETTA, T. FINOTTI, I. Igreja Renascer assume Rede Manchete. Folha de São Paulo, São Paulo, 1999. Disponível em:

$<$ http://www1.folha.uol.com.br/fsp/dinheiro/fi05019919.htm>. Acesso em: 27 out. 2015.

Recebido em: $31 / 07 / 2015$

Aceito em: 06/10/2015

Publicado em: 04/12/2015 